\title{
ON THE SUITABILITY OF THE DISTANCE BETWEEN THE TIP OF THE NOSE AND THE MIDDLE OF THE ELBOW JOINT FOR SNEEZING ETIQUETTE AS CORONA INFECTION PROPHYLAXIS
}

\author{
Christoph Raschka ${ }^{1}$, Laura Heer ${ }^{1}$, Horst Josef Koch $^{2}$ \\ ${ }^{1}$ Institute of Sports Sciences, Julius Maximilian University, Würzburg, Germany \\ ${ }^{2}$ Heinrich-Braun-Klinikum, Zwickau, Germany
}

\begin{abstract}
During the current corona pandemic, the question to which extent people could reach the middle of the elbow joint with the tip of their nose, which the Federal Ministry of Health recommended as a preventive measure when sneezing, was investigated with the help of an online questionnaire.

The analysis included 316 fully completed online questionnaires and 16 additional telephone interviews, a total of 332 test persons (average age 29.5 ( \pm 14.3 ) years, average BMI $22.9( \pm 3.4) \mathrm{kg} / \mathrm{m}^{2} ; 226$ women, $\left.106 \mathrm{men}\right)$.

The results of this study show that $84.6 \%$ of respondents followed the recommended coughing etiquette and sneezed into the crook of their arm, $15.4 \%$ did not. The most common reason given for not using it was habit. Nevertheless, $92.8 \%$ of the participants found sneezing or coughing in the crook of their arm to be useful.

When measuring the distance, $76.2 \%$ of the participants were able to touch the crook of the arm at the specific angle on both sides. The average measured distance was $1.13 \mathrm{~cm}$ on the right and $1.23 \mathrm{~cm}$ on the left. It was found that the BMI and age had a significant relationship with the measured distance. In a gender-specific comparison, more women than men sneezed into the crook of their arm, while no significant differences were found when measuring the distance.

If the results of this study are put into practice, it makes perfect sense to continue to recommend sneezing or coughing in the crook of the arm. However, a note should be attached to this recommendation, which prompts one to take the sneeze position once and to check whether the crook of the arm
\end{abstract}


can really be reached effectively. If this is not possible, alternative options should be recommended.

Keywords: cough etiquette; sneeze etiquette; anthropometry; elbow joint centre; corona pandemic; practicability

\section{INTRODUCTION}

Since the corona virus spreads exponentially and, thus, is extremely virulent, a general means had to be found to contain the spread of the virus with the simplest possible behaviour that is accessible to the general public in every situation. When transmitted, aerosols, micro-fine droplets, are released into the environment through coughing or sneezing and absorbed through the mucous membranes of the other persons [6,7]. Even before the Covid-19 pandemic, the Federal Ministry of Health of Germany recommended sneezing or coughing in the crook of the arm or a paper tissue as a preventive measure [3]. In an impact analysis of the prevention work against the corona virus, $83 \%$ of the respondents fully agreed with the statement that they sneeze into a handkerchief or the crook of their arm [4].

So far, there have been no substantial studies whether people are able to reach the crook of the arm with the expiratory end organ to justify the recommendation of the Federal Ministry of Health on infection and disease protection. The effectiveness and efficiency also depend on the distance between the nose or mouth and the crook of the arm. The closer the distance, the better can the transmission of pathogens into the ambient air be prevented.

The data on an individual's sneezing behaviour was collected using an online questionnaire. Further questions focused on influencing factors such as age, body weight, doing weight training, etc.

The lack of profound knowledge about the effectiveness of the cough etiquette is also reflected in a meta-analysis [8] and has been criticized. If you follow [10], the aerosols emitted when coughing are not completely reduced by the cough etiquette but nevertheless reduced by a certain percentage. Other researchers [13] have also reached a similar conclusion: Despite the cough etiquette, infected cough droplets can still be released into the environment. How strong the proportion of retained particles is, however, could not be determined here. 
Using a face mask is said to be more suitable for infection protection than using the crook of the arm [8]. However, none of these measures are sufficient to completely block the cough droplets [13].

A correct anatomical position between the shoulder joint, the elbow and the tip of the nose is essential to prevent the spread and transmission of pathogens when coughing or sneezing.

There are already several approaches to keep the particles emitted by coughing and sneezing as close to the source as possible. Because sneezing is a protective reflex and thus requires the ability to act quickly, using the crook of the arm seems to be a practicable solution due to its quick accessibility [9].

This paper examines whether the distance between the tip of the nose and the middle of the elbow joint is so small in the population that it is effective to use the coughing etiquette recommended by the Federal Ministry of Health to protect against infection.

\section{MATERIAL AND METHODS}

The data was collected in the form of a standardised written questionnaire that was placed online for 14 days.

Older relatives and friends who do not use social media could also be interviewed in a personal telephone conversation.

All participants received a pool of 25 questions via a computer-aided survey. The number of questions to be answered varied depending on the answers given. In terms of content, the pool of questions can be divided into four sections: personal data (age, gender, height, weight, BMI, handedness, exercise (weight training)), existing diseases (cervical spine, shoulder), sneezing behaviour (use of the crook of the arm) and measurement (distance on the right vs. left, acute and right angles). Before the study participants could start, they had to agree to a declaration of consent for the data to be collected.

A total of 502 people opened the link to the "Unipark" platform. 361 participants agreed to the privacy policy and started answering the questions. After checking for correctness and completeness, 316 online questionnaires could be included in the empirical analysis.

As the measurement of the distance was the primary question, questionnaires with incomplete or non-existent measurements were not included in the analysis.

Accordingly, the study consisted of 316 online questionnaires and 16 participants' replies to the telephone survey from a total of 332 test persons. 


\section{RESULTS}

The average age of the participants is 29.5 ( \pm 14.3 ) years (age range 15-85 years). The age groups between 20 and 25 years predominate strongly.

With 226 female and 106 male participants, the ratio of women to men is around 2:1.

The weight of the lightest person is $46 \mathrm{~kg}$ and that of the heaviest person $120 \mathrm{~kg}$ (average: $68.2 \pm 13.3 \mathrm{~kg}$ ). The average height of $1.72( \pm 0.09) \mathrm{m}$ results in an average BMI of $22.9( \pm 3.4) \mathrm{kg} / \mathrm{m}^{2}$.

$87.3 \%$ of the respondents were right-handed $(\mathrm{n}=290), 12.7 \%$ left-handed $(\mathrm{n}=42)$.

The majority $(57.5 \%$; $n=191)$ were wearing items of clothing such as T-shirts and tops at the time of the measurement.

A total of 40 participants (12\%) reported a restriction in the area of the cervical spine or shoulder. $6.3 \%(n=21)$ mentioned a specific disease in the area of the cervical spine: malpositions $(47.6 \% ; \mathrm{n}=10)$; muscle induration $(19 \% ; n=4)$ and damage to the nerves $(33.3 \% ; n=7)$.

In the shoulder area, a total of 19 participants (5.7\%) suffered from the following categories: movement restrictions $(47.4 \%, \mathrm{n}=9)$, damage to the nerves $(21.1 \%, \mathrm{n}=4)$, ruptures $(15.8 \%, \mathrm{n}=3)$ and fractures $(15.8 \%, \mathrm{n}=3)$. The right side was affected in ten and the left in twelve of the people surveyed.

With $76.8 \%(n=255)$, the majority of the participants stated that they practised sports regularly (women: $73 \%(n=165)$, men: $84.9 \%(n=90)$; the average sporting activity per week was $4.81( \pm 3)$ hours, maximum 18 hours. $25.5 \%$ $(n=65)$ of those involved in sports regularly practised two or more sports.

In addition, the sports involved had to be named. These were then divided into four categories: weight training $(47.1 \% ; \mathrm{n}=120)$, endurance $(37.6 \%$; $\mathrm{n}=96)$, ball games $(23.1 \% ; \mathrm{n}=59)$, dance and mobility $(17.3 \% ; \mathrm{n}=44)$. Weight training was performed on average $3.5( \pm 2)$ hours per week (maximum 10 hours per week).

The survey of sneezing behaviour showed that a total of $84.6 \%(n=281)$ of the participants sneezed or coughed in the crook of their arm. In a comparison of the two sexes, women $(n=196)$ used the crook of the arm more often than men $(\mathrm{n}=85)$.

According to this, $15.4 \%(n=51)$ of the respondents did not cough or sneeze into the crook of their arm. These participants also had to explain why they did not do it. The reasons given by these 51 participants were divided into three categories: habit $(52.9 \% ; \mathrm{n}=27)$, feelings of disgust due to poor hygiene $(41.2 \% ; \mathrm{n}=21)$ and restricted mobility $(5.9 \% ; \mathrm{n}=3)$. 
With $92.8 \%(\mathrm{n}=308)$, the majority consider sneezing or coughing in the crook of their arm useful. Here, too, the female respondents predominate with $95.1 \%(\mathrm{n}=215)$ compared to the males with $87.7 \%(\mathrm{n}=93)$. Nevertheless, $15.9 \%(\mathrm{n}=49)$ of those who consider this method to be suitable, do not use the crook of the arm for coughing or sneezing.

Table 1. Descriptive statistics of the measurement in the smallest angle $(\mathrm{cm})$.

\begin{tabular}{lcccccc}
\hline & $\begin{array}{c}\text { Right } \\
\text { (total) }\end{array}$ & $\begin{array}{c}\text { Left } \\
\text { (total) }\end{array}$ & $\begin{array}{c}\text { Right } \\
\text { (women) }\end{array}$ & $\begin{array}{c}\text { Left } \\
\text { (women) }\end{array}$ & $\begin{array}{c}\text { Right } \\
\text { (men) }\end{array}$ & $\begin{array}{c}\text { Left } \\
\text { (men) }\end{array}$ \\
\hline MAX & 15 & 15 & 10 & 10 & 15 & 15 \\
\hline Mean & 1.13 & 1.23 & 0.94 & 1.04 & 1.51 & 1.65 \\
\hline SD & 2.55 & 2.72 & 2.13 & 2.28 & 3.24 & 3.46 \\
\hline
\end{tabular}

When measuring the distance between the tip of the nose and the middle of the elbow joint in smallest angles, $78 \%(\mathrm{n}=259)$ of the participants reached the right elbow and 77.4\% $(\mathrm{n}=257)$ the left elbow with a distance of $0 \mathrm{~cm}$. $76.2 \%(n=253)$ of the participants reached both the right and left sides. The measured distance of all elbow targets at the smallest angle averages $1.18 \mathrm{~cm}$.

When measured at a 90-degree angle, a total of 59.9\% $(n=199)$ of the participants reached both the left and the right elbow. The right elbow, like the left, was touched by $60.8 \%(n=202)$. The average distance of all measured elbow targets at right angles was $3.18 \mathrm{~cm}$.

Table 2. Descriptive statistics of measurements at a 90-degree angle (cm).

\begin{tabular}{lcccccc}
\hline & $\begin{array}{c}\text { Right } \\
\text { (total) }\end{array}$ & $\begin{array}{c}\text { Left } \\
\text { (total) }\end{array}$ & $\begin{array}{c}\text { Right } \\
\text { (women) }\end{array}$ & $\begin{array}{c}\text { Left } \\
\text { (women) }\end{array}$ & $\begin{array}{c}\text { Right } \\
\text { (men) }\end{array}$ & $\begin{array}{c}\text { Left } \\
\text { (men) }\end{array}$ \\
\hline MAX & 25 & 26 & 18 & 19 & 25 & 26 \\
\hline Mean & 3.14 & 3.22 & 3.04 & 3.06 & 3.34 & 3.57 \\
\hline SD & 4.83 & 4.99 & 4.33 & 4.46 & 5.76 & 5.98 \\
\hline
\end{tabular}

9.6\% ( $\mathrm{n}=198)$ of the participants reached the middle of the elbow joint with the tip of their nose at both a very small and a right angle. In both positions, $60.8 \%(n=202)$ reached the right elbow and $60.5 \%(n=201)$ reached the left elbow.

At the 90-degree angle, men with $62.3 \%(\mathrm{n}=66)$ are ahead of women with $58.8 \%(\mathrm{n}=133)$. The very small angle, on the other hand, is achieved by $77.4 \%$ $(n=175)$ of women and $73.6 \%(n=78)$ of men. More men $(63.2 \% ; n=67)$ 
than women $(59.7 \% ; \mathrm{n}=135)$ touch the right elbow with the tip of their nose at a very small and a 90-degree angle. The crook of the left arm is also reached by more men than women $(58.8 \% ; n=133)$ with $64.2 \%(n=68)$.

An interesting result was a weak but very significant contingency coefficient of $r=0.2$ between the BMI and reaching the crook of the arm at a very small angle ( $\mathrm{p} \leq 0.01)$. When comparing the two sides of the body, the BMI and the left arm with $\mathrm{r}=0.4$ have a stronger relationship than the BMI and the right arm with $\mathrm{r}=0.34(\mathrm{p} \leq 0.001)$.

People with a higher BMI reached the crook of the arm less often. While around $80 \%$ of the participants with a $\mathrm{BMI}<25 \mathrm{~kg} / \mathrm{m}^{2}$ meet the various elbow goals, less than $70 \%$ with a BMI $>25 \mathrm{~kg} / \mathrm{m}^{2}$ do. From a BMI of $>30 \mathrm{~kg} / \mathrm{m}^{2}$, the percentage of people who can touch the crook of the arm drops to a half.

Both the mean measured distance from the tip of the nose to the middle of the elbow joint and the standard deviation are significantly higher for people with a BMI of over $35 \mathrm{~kg} / \mathrm{m}^{2}$ than for the other BMI classes.

Table 3. Descriptive statistics of the measured distance according to various BMI classifications $(\mathrm{cm})$.

\begin{tabular}{|c|c|c|c|c|c|}
\hline BMI & $\begin{array}{l}<18.5 \\
\mathrm{~kg} / \mathrm{m}^{2}\end{array}$ & $\begin{array}{c}18.5-24.9 \\
\mathrm{~kg} / \mathrm{m}^{2}\end{array}$ & $\begin{array}{c}25-29.9 \\
\mathrm{~kg} / \mathrm{m}^{2}\end{array}$ & $\begin{array}{c}30-34.9 \\
\mathrm{~kg} / \mathrm{m}^{2}\end{array}$ & $\begin{array}{c}35-39.9 \\
\mathrm{~kg} / \mathrm{m}^{2}\end{array}$ \\
\hline Max & 14 & 25 & 26 & 12 & 17 \\
\hline Mean & 2 & 1.89 & 3.1 & 2.23 & 5.69 \\
\hline SD & 3.6 & 3.34 & 4.86 & 3.3 & 6.8 \\
\hline
\end{tabular}

\section{DISCUSSION}

Due to soft tissue inhibition, increased fat deposits in obese people can lead to restricted mobility. Touching the elbow joint is particularly difficult due to the limited flexion of the arm $[11,12]$. The percentage of participants who can touch the crook of their arm is significantly lower in people with obesity grade I and above (BMI $30-34.9 \mathrm{~kg} / \mathrm{m}^{2}$ ). A greater increase in the mean measured distance can be seen from obesity grade II (BMI $35-39.9 \mathrm{~kg} / \mathrm{m}^{2}$ ).

Regarding the distance measurement and gender, no significant differences could be found.

Sneezing behaviour, on the other hand, has a very significant relationship of $r=0.17$ with gender.

Although the results of a study show that the passive range of motion of the shoulder girdle is 3-7 degrees greater in women than in men [1], this does not 
appear to be an influencing factor on the measurement of the distance between the tip of the nose and the middle of the elbow joint. When flexing the cervical spine, however, no gender-specific dependency could be determined [5].

As already shown in the results, proportionally more women $(86.7 \%)$ than men $(80.2 \%)$ sneeze into the crook of their arm. The reason for this could be that women are more hygienic than men. This has also been made clear by a survey on hand washing behaviour in various situations, in which the percentage of men who washed their hands was lower than the percentage of women in all areas [2].

No significant correlation was found between strength training and the measured distance. The average number of hours of 3.5 hours per week suggests that the existing muscle mass is too low to measurably influence the flexion of the arm. Measurements on highly trained bodybuilders could possibly produce completely different results.

Pearson's contingency coefficients of $r=0.37(r=0.4)$ were determined (in both cases $\mathrm{p} \leq 0.001$ ) between age and the measurements of the left (right) arm.

From the age group of 15-19 years up to and including 40-49 years, around $80 \%$ of the participants achieved the various elbow targets. Less than half of the 50-59-year-olds, however, touched the crook of the arm. Exactly half of the participants over 59 years of age reached the crook of their arm.

As can be seen in Table 4, the measured values deteriorate from the age group of 50-59 years. With a mean value of $4.33 \mathrm{~cm}$, the age group of 50-59 years had the greatest average distance when measuring.

Table 4. Descriptive statistics of the measured distance according to the age groups $(\mathrm{cm})$.

\begin{tabular}{lcccccc}
\hline & $\begin{array}{c}\mathbf{1 5 - 1 9} \\
\text { years }\end{array}$ & $\begin{array}{c}\mathbf{2 0 - 2 9} \\
\text { years }\end{array}$ & $\begin{array}{c}\mathbf{3 0 - 3 9} \\
\text { years }\end{array}$ & $\begin{array}{c}\mathbf{4 0 - 4 9} \\
\text { years }\end{array}$ & $\begin{array}{c}\mathbf{5 0 - 5 9} \\
\text { years }\end{array}$ & >59 years \\
\hline Max & 26 & 25 & 20 & 13 & 17 & 19 \\
\hline Mean & 2.18 & 1.6 & 2.53 & 2.05 & 4.33 & 4.03 \\
\hline SD & 3.62 & 3.31 & 4.37 & 3.82 & 4.42 & 4.47 \\
\hline
\end{tabular}

Age-related changes lead to a decrease in motor performance as mobility and muscle strength decrease with advancing age.

When checking the relationship between body size, restrictions in the cervical spine area and the measured distance, the contingency coefficient did not yield any statistically significant values. 
Regarding previous damage to the shoulder and the distance, there was only a very significant correlation on the left side with $r=0.2$. There were no significant differences in terms of handedness.

In practice, sneezing and coughing into the crook of the arm are an effective and practicable prevention method for people who can reach it. However, $23.8 \%$ of those surveyed could not reach the crook of the arm at a small angle. It can be assumed that these people will not be able to effectively prevent pathogenic bacteria and viruses from being passed on to the ambient air or from being deposited on objects.

Nevertheless, in the current pandemic stage, this sneeze etiquette is still strongly recommended. However, people should be made aware that infection protection based on this recommendation only occurs if done correctly. It is important that each person should reflect critically on the effectiveness of their own execution. For those who cannot reach the crook of their arm, alternative solutions must be considered, such as sneezing into a tissue but also turning away and keeping their distance from other people as an additional measure.

Due to the predominant use of social media by the younger generation, the age groups of $20-29$ years $(n=180)$ and $15-19$ years $(n=43)$ were certainly strongly represented in the present study. Accordingly, the representativeness of the sample is limited in comparison to the total population. To prevent this, a quota sample would have been better instead of the ad-hoc sample used in this study, but, due to existing contact restrictions, this was not implemented during the pandemic for safety reasons. However, the percentage of people who cannot reach the crook of their elbows while sneezing would have been significantly higher.

\section{REFERENCES}

1. Anetzberger H., Lipold F., Birkenmaier C. et al. (2013). Der passive Bewegungsumfang von gesunden Schultern. Obere Extremitäten, 8, 212-219. https://doi.org/10.1007/s11678-013-0229-x [Accessed June 10, 2020].

2. BZgA (2013). Einstellungen, Wissen und Verhalten der Allgemeinbevölkerung zu Hygiene und Infektionsschutz, p. 78. Köln: BZgA.

3. BZgA (2020). Hygiene. Ganz einfach gesund bleiben: Tipps für das Hygieneverhalten. Eine Information für Eltern. Köln: BZgA https://www.bundesgesundheitsministerium.de/fileadmin/Dateien/3_Downloads/A/Asylsuchende/ Hygieneverhalten_62530100.pdf [Accessed June 24, 2020].

4. Hermann M. (2020). Wirkanalyse der Präventionsarbeit des Bundesamts für Gesundheit BAG im Bezug auf das neue Coronavirus, p. 6-11. BAG 
5. Pogrzeba M.R. (2008). Einfluss von Alter, Geschlecht und Bewegungsgeschwindigkeit auf die elektrische Aktivität des Musculus semispinalis capitis und das Bewegungsausmaß der Halswirbelsäule bei Flexions-, Extensions- und Rotationsbewegungen, p. 15-40 https://search.datacite.org/works/10.18725/oparu1622 [Accessed June 23, 2020].

6. RKI (2020a). RKI - Coronavirus SARS-CoV-2 - SARS-CoV-2 Steckbrief zur Coronavirus-Krankheit-2019 (COVID-19). Available at: https:// www.rki.de/DE/Content/InfAZ/N/Neuartiges_Coronavirus/Steckbrief. html\#doc13776792bodyText1 [Accessed May 17, 2020].

7. RKI (2020b). SARS-CoV-2 Steckbrief zur Coronavirus-Krankheit-2019 (COVID-19). Available at: https://www.rki.de/DE/Content/InfAZ/N/Neuartiges_Coronavirus/ Steckbrief.html\#doc13776792bodyText1 [Accessed June 12, 2020].

8. Saunders-Hastings P., Crispo J.A.G., Sikora L. et al. (2017). Effectiveness of personal protective measures in reducing pandemic influenza transmission: A systematic review and meta-analysis. Epidemics, 20, 1-20. https://doi.org/10.1016/j.epidem.2017.04.003 [Accessed June 09, 2020].

9. Sommer F., Scheithauer M., Kröger R. et al. (2014). Niesen als mechanische Abwehr - Numerische Simulation mit Analyse der durchströmten Nasenbereiche. Laryngo-Rhino-Otologie, 93(11), 746-750. https://doi.org/10.1055/s-0034-1385862 [Accessed June 13, 2020].

10. Wood M.E., Stockwell R.E., Johnson G.R. et al. (2018). Face Masks and Cough Etiquette Reduce the Cough Aerosol Concentration of Pseudomonas aeruginosa in People with Cystic Fibrosis. American Journal of Respiratory and Critical Care Medicine, 197(3), 348-355. https://doi.org/10.1164/rccm.201707-1457OC

11. Wurzinger L.J. (2017a). Schulter. In: Duale Reihe Anatomie. Stuttgart: Thieme. https://eref.thieme.de/4WQEZ [Accessed June 2, 2020].

12. Wurzinger L.J., Aumüller G., Aust G. et al. (2017b). Ellenbogengelenk (Articulatio cubiti). In: Duale Reihe Anatomie. Stuttgart: Thieme. https://eref.thieme.de/KAPF5 [Accessed June 2, 2020].

13. Zayas G., Chiang M., Wong E. et al. (2013). Effectiveness of cough etiquette maneuvers in disrupting the chain of transmission of infectious respiratory diseases. BMC Public Health, 13, 811, 1-11.

https://doi.org/10.1186/1471-2458-13-811

\section{Adress for correspondence}

Christoph Raschka

Institute of Sports Sciences

Julius Maximilian University

Judenbühlweg 11, D-97082 Würzburg, Germany

E-mail: christoph.raschka@uni-wuerzburg.de 